\title{
Tsangnyön Herukas sånger
}

Milarepas sånger var förmodligen den främsta inspirationskällan när Tsangnyön skapade sina sånger. ${ }^{119}$ Sångernas form, struktur och bildspråk ingår i en tibetansk sångtradition med rötter långt tillbaka i den tibetanska historien. ${ }^{120}$ Sångernas innehåll påminner dock tydligt om de indiska fullkomnade mästarnas, de så kallade siddhornas, sånger. ${ }^{121}$ Återkommande teman i siddhornas sånger var användandet av paradoxer; kritik mot sociala, kulturella och religiösa normer; fokus på det medfödda, självuppstådda och naturliga ( $\mathrm{t}$ : lhan gcig; s: sahaja); en positiv syn på kroppen, sinnesnjutning och sexualitet; ett förordande av vissa yogiska tekniker; hyllning till och vördnadsbetygelse för den andliga läraren. ${ }^{122}$ Många av dessa teman förekommer regelbundet i såväl Tsangnyöns och Milarepas sånger som i andra tibetanska mästares sånger.

När Marpa reste till Indien och Nepal på tusentalet träffade han Nāropa, Maitrīpa samt flera andra av de mest framstående siddhorna i Indien och Nepal. Han lärde sig deras sånger och efter hand började han själv uttrycka sin insikt via sånger. Marpa förmedlade senare denna sångtradition vidare till sin tibetanska lärjunge Milarepa. Milarepa kom att bli Tibets mest välkända och älskade diktare, vida känd för sina djupsinniga och direkta sånger, och för sin ovanligt vackra sångröst. På detta sätt spreds sångtraditionen i Tibet, och flera hundra år senare fick Tsangnyön ta del av den genom sin huvudsakliga lärare, Shara Rabjampa Sangye Senge. ${ }^{123}$ Efter långvariga studier och intensiv utövning blev Tsangnyön själv en fullkomnad mästare, och när han närmade sig trettio års ålder började han, som nämnts ovan, sjunga sånger där han uttryckte sina insikter. Tsangnyön sjöng, får vi förmoda, på ett meditativt, rytmiskt, melodiskt och vackert sätt. Det är rimligt att anta att melodierna som han använde sig av 
härstammade både från Tibet och Indien, och att de gått i arv från mästare till lärjunge i århundraden.

I Att skingra okunnighetens mörker och öppna hängivenhetens ögon som Tsangnyön författade 1503 skriver han följande om sånger:

På indiska språk kallas sångerna för gìti och på tibetanska för glu eller dbyangs. När de segerrikas upplysta intentioner och ens egna önskningar versifieras och framförs med en melodi, så kallas de för glu eller dbyangs. När de uttrycker [förverkligandets] storslagenhet kallas de för $m g u r .{ }^{124}$

Numera används vanligtvis termen mgur (uttalas: $g u r$ ) för den här typen av buddhistiska sånger.

Tsangnyöns sånger liknar Milarepas på många sätt, och sannolikt använde han sig ibland av samma melodier som Milarepa. ${ }^{125}$ Både Tsangnyöns och Milarepas sånger handlar ofta om grundläggande buddhistiska ämnen såsom sinnets sanna natur, det dyrbara människolivet, alltings förgänglighet, hur viktigt det är att aldrig göra något som skadar andra och hur mycket lidande och otillfredsställelse det finns i tillvarons kretslopp. Liksom Milarepa sjöng Tsangnyön om hur man tar sig bort från detta lidande, och om hur man uppnår befrielse och uppvaknande.

Sångerna som Tsangnyön sjöng ingår i en tradition som är mycket gammal, men de var anpassade till den tid och den plats där de sjöngs. Denna syntes av gammalt och nytt gjorde sångerna tidlösa, vilket säkert bidrog till att de som lyssnade till dem upplevde dem som genuina. I stället för liknelser hämtade från indisk kultur valde Tsangnyön, precis som Milarepa en gång hade gjort, att låta sådant som åhörarna var bekanta med åskådliggöra sångens budskap. Eftersom det fanns utrymme för innovationer och anpassningar till den tibetanska kulturen och det tibetanska kynnet, bidrog sångerna till att göra buddhismen begriplig och angelägen för tibetanerna. Tsangnyön tydliggjorde sina sångers budskap genom att dra paralleller till hästridning, bågskytte, årstider, värme, kyla, vatten och is. Bildspråket är enkelt och tydligt och skiljer sig från den mer ornamenterade och indiskt influerade poesi som också var populär i Tibet under denna period (t: snyan ngag; s: kāvya). Genom att använda enkla 
och vardagliga liknelser, hämtade från den omgivning som han själv och sångernas åhörare var bekanta med, kunde Tsangnyön göra sig förstådd. Följande utdrag ur sången till härskaren Samdrub De, som vi har anledning att återkomma till, är ett tydligt exempel:

Jag har vattnat det opartiska grundmedvetandets åker med fixerat fastklängande.

Och efter att ha sått det orena sinnets frö, plogade jag med plogoxarna som delar upp i subjekt och objekt. Efter att ha jämnat ut plogfårorna med högmodets harv, var skotten på väg att komma upp.

Men just när de fem gifterna höll på att slå rot i mitt sinne, vände floden av mina karmiska meriter.

Och min traditions välsignelser forsade in i åkerns bevattningskanaler. Detta kombinerades med trons, hängivenhetens och medkänslans torka.

Därför kunde de fem gifterna inte mogna i mitt sinne.

Efter detta kom några enstaka

dåliga skott upp här och var, men begärets och fastklängandets gödning saknades.

Under lång tid brändes skotten, de torkade ut i den varma solen - traditionens medkänsla.

Därför kunde inte de dåliga skotten mogna i sinnet. ${ }^{126}$

Tsangnyöns sånger har, enligt hans lärjungar, en mängd häpnadsväckande och transformerande egenskaper. Bland annat renar de från negativa gärningar och skymmande slöjor. Sångerna är, fortsätter de, "den oöverträffade medicinen som förvandlar de fem gifterna till de fem visdomarna, den stora elden som förbränner jaguppfattningens ved. De är generalen som besegrar fienden - det dualistiska klängandet. Sångerna är det heliga skeppet som befriar varelserna från samsāras ocean." 127

Den första sången i sångsamlingen sjöng Tsangnyön i Lachi då han var i tjugoåttaårsåldern. Efter denna sång kommer en serie sånger som är riktade till en av Tsangnyöns närmaste lärjungar, Rinchen Palsangpo. Dessa sånger innehåller djupsinniga instruktioner om sin- 


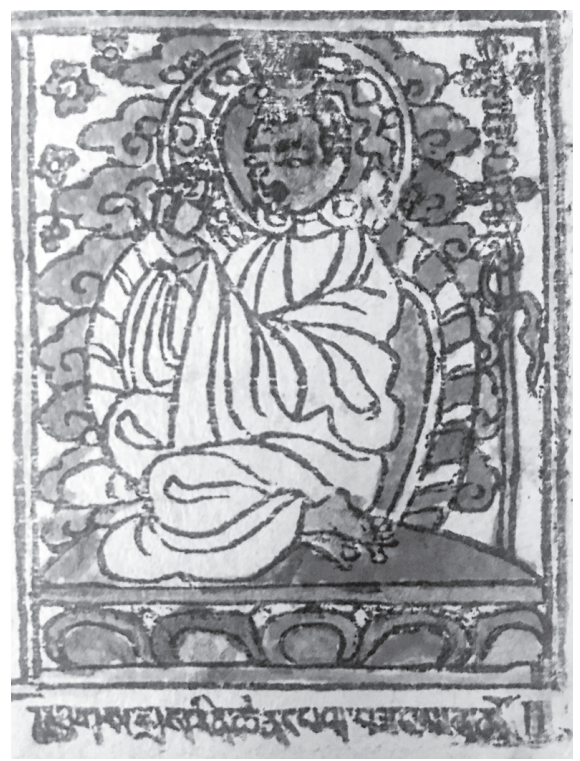

Bild 9. Hjärtesonen Rinchen Palsangpo (gTsang smyon he ru ka, gTsang pa he ru ka'i mgur 'bum: 1b).

nets natur och fick Rinchen Palsangpo att känna igen sitt "naturliga tillstånd”. Följande korta utdrag ur en av dessa sånger får exemplifiera hur dessa instruktioner kan vara formulerade:

O du lyckligt lottade, bestig den oföränderliga hängivenhetens häst! Med den hörda traditionens pil och båge, spänn en armlängd av de mest kärnfulla muntliga instruktionerna. Efter att ha satt meditationsutövandets häst i galopp, sikta med den självigenkännande visdomens pil på det ofödda sinnet, alltings grund - saṃsāras såväl som nirvāṇas - och håll fast vid målet! $!^{128}$

Därefter följer flera sånger till kungen av Mangyul Gungtang och dennes söner. Det är framför allt en av denna mäktiga konungs söner, prins Samdrub De, som figurerar i sångsamlingen. Denna prins, eller kung som han också ibland kallas i sångsamlingen, tvivlade på att Tsangnyön verkligen var en uppvaknad mästare. Tsangnyöns 
till synes galna uppförande och okonventionella beteende gjorde att Samdrub De hade svårt att känna förtroende för honom. I en kort sång anklagar Samdrub De Tsangnyön för att vara en galning och tiggare. Dessutom kallar han honom för slö, likgiltig och omogen. Tsangnyön besudlar Milarepas heliga platser genom att vistas på dem, menar Samdrub De i sin kritiska sång. ${ }^{129}$ Tsangnyön svarar Samdrub De med en sång som är den längsta i sångsamlingen, "Den storslagna sången som visar hur tillkortakommanden i själva verket kan vara goda egenskaper”. Denna sång är en av sångsamlingens höjdpunkter. Här finns många exempel på hur Tsangnyön med lekfullhet, skärpa och lärdom förmedlar vad han anser vara viktigt när man utövar buddhismen. I sången förklarar Tsangnyön varför kungen har rätt när han anklagar Tsangnyön för att vara galen. Tsangnyöns galenskap är dock inte av det vanliga slaget, utan en uppvaknandets galenskap:

Synsättet

- föreningen, bortom begränsningar -

har gjort mig galen.

Meditationen

- klarhet, tomhet, bortom fastklängande har gjort mig galen.

Uppförandet

- att trampa ner rädslor -

har gjort mig galen.

Grunden

- bortom alla överdrifter har gjort mig galen.

Vägen

- att avstå från negativa handlingar

och utöva goda handlingar -

har gjort mig galen.

Resultatet

- att ha känt igen min egen verkliga natur har gjort mig galen.

$[\ldots]$ 
Om denna typ av galenskap skulle uppstå, vore det bra om också kungen själv blev galen. ${ }^{130}$

Sången övertygade Samdrub De om att Tsangnyön var en förverkligad yogi, väl värd att stödja. Han fylldes av hängivenhet och Tsangnyön hade fått ytterligare en mäktig välgörare.

Efter denna sång kommer några andra sånger riktade till kungligheterna från Gungtang. En av dessa sånger visar att kungarna ibland kunde bete sig riktigt illa och till och med stjäla från folket. I sången tillrättavisar Tsangnyön kungen av Gungtang som stulit en dyrbar vas från en fattig pilgrim. Han påpekar bland annat att "en kung ska ge trygghet till de kännande varelserna, men att kungen nu agerat på ett hotfullt sätt", och att "en rättfärdig kung ska bestraffa tjuvar, men att kungen själv nu uppfört sig som en tjuv". ${ }^{131}$ Sången innehåller undervisning om orsak och verkan, och den får kungen att ångra sin missgärning samt lämna tillbaka det han stulit. Denna sång vittnar om att Tsangnyön hade avsevärd makt och inflytande. Den galna yogin kunde, enligt sången, få en mäktig kung att ändra sitt beteende.

Tsangnyöns sånger riktar sig i allmänhet antingen till någon av hans lärjungar eller till härskare. Eftersom härskarna också ofta var lärjungar till Tsangnyön går det dock inte att dra någon tydlig gräns mellan dessa bägge kategorier. Tsangnyöns närmaste lärjungar, eller "hjärtesöner" som de ofta benämns i sångsamlingen, var dock i allmänhet yogier som hade lämnat det världsliga livet bakom sig. De manliga och kvinnliga yogier som hade Tsangnyön som sin huvudsakliga lärare hade få ägodelar och levde ett kringvandrande liv som påminde om det som Tsangnyön själv levde. Deras vandringar varvades med intensiv meditation i något avlägset beläget eremitage. Härskarna och härskarinnorna som blev lärjungar till den galna yogin levde på ett helt annat sätt - omgivna av militärer, vakter, drottningar, prinsessor, prinsar, barn och tjänare vistades de i fort eller, om de var på resa, i tältstäder.

Tsangnyön uppmanar ibland åhörarna att lämna det världsliga livet och bli kringvandrande eremiter utan någon fast bostad. Han uppmanar till exempel härskarinnan Sönam Sangmo att "se hur det som byggts upp faller samman" och "vandra runt i vildmark och bland 
ensliga boningar". "Om du önskar kontinuerlig lycka och glädje, fly från saṃsāras fängelsehålor", fortsätter Tsangnyön i denna sång. ${ }^{132}$

I en annan sång, till hjärtesonen Möndze Togdenpa, påpekar Tsangnyön att det inte räcker med att leva asketiskt. Om vi "inte är fria från materiella begär när vi vandrar land och rike kring", eller "överväldigas av världsliga begär när vi vandrar i ensliga bergsområden, utan följeslagare" gör vi fel. ${ }^{133}$ Det är sinnet som är det centrala, och buddhistisk asketism handlar framför allt om en inre hållning.

Några av sångerna, till exempel sången till Sönam Sangmo, skrevs ner av Tsangnyön och skickades sedan. De flesta sångerna i sångsamlingen verkar dock ha uppkommit spontant och komponerats i stunden som respons på olika situationer som Tsangnyön ställts inför, eller som svar på direkta frågor. Sångerna förefaller således i allmänhet ursprungligen ha varit muntligt framförda och spontant skapade i det ögonblick då de framfördes. Sångerna memorerades sedan av åhörarna och skrevs ner av Tsangnyöns hängivna lärjungar först efter att de framförts. Det kan måhända vara svårt att förstå hur det är möjligt för åhörarna att memorera långa sånger framförda på vers, och det är förstås omöjligt att med säkerhet fastställa om sångerna verkligen var spontant framförda och först senare nedtecknats, eller om de i själva verket var komponerade från början. Det bör dock inte uteslutas att sångerna kan ha uppstått spontant, memorerats och senare skrivits ner såsom traditionen gör gällande.

Merparten av sångerna börjar med en hyllning till Tsangnyöns lärare, Sharawa. Det är vanligt att inleda buddhistiska sånger av detta slag med en vördnadsbetygelse för sin lärare. Läraren anses vara mycket viktig i buddhismen överlag och i synnerhet i den tantriska buddhismen. Utan hans eller hennes välsignelse och instruktioner varken kan eller får man utöva de esoteriska utövningsmetoder som Tsangnyön och hans lärjungar ägnade sig åt. Tsangnyön påpekar $\mathrm{i}$ Att skingra okunnighetens mörker och öppna hängivenhetens ögon, som handlar om buddhistiska sånger, att "ingen recitation är mer effektiv än hyllning till och vördnad för sin lärare". ${ }^{134}$ Läraren anses vara essensen av hela tillflykten. Hans sinne är buddha, hans tal är dharma och hans kropp är sangha.

Sångerna omgärdas i allmänhet av en mer eller mindre utförlig ramberättelse, där det anges var sångerna sjöngs och till vem eller 
vilka sångerna riktades när det begav sig. Denna narrativa kontext är viktig för förståelsen av sången. Där anges ofta omständigheterna och orsakerna till varför Tsangnyön sjöng sången. Ibland beskrivs också platsen där sången sjöngs samt de personer som figurerar i den. Relationen mellan själva sångerna och deras narrativa kontext kan jämföras med den relation som råder mellan pratbubblorna och bildrutorna i en modern serietidning. Utan texten i pratbubblorna (sångerna) blir serietidningen svår att förstå, och utan själva bilderna (ramberättelsen som omger sångerna) som visar vem som säger vad, till vem, var, och så vidare, så är det inte heller möjligt att tillgodogöra sig handlingen.

Även om Tsangnyön ofta kallar sig själv för "en galen yogi" eller "dåre" i sångerna, så lyser det galna och okonventionella med sin frånvaro i de flesta sånger. I stället är det en relativt traditionell form av buddhism som Tsangnyön förkunnar. De fyra tankarna som vänder sinnet mot dharma, den dyrbara människokroppen, förgängligheten, orsak och verkans ofrånkomlighet och samsāaras bristfällighet är ämnen som Tsangnyön ofta återkommer till. Dessa tankar är särskilt vanliga i sånger som riktar sig till härskare, härskarinnor och lekfolk i allmänhet. Följande utdrag ur en sång till kung Sherab Palsang är ett tydligt exempel:

$\mathrm{O}$, gudomlige son, härskare, Sherab De,

du säger att du behöver den heliga läran som gagnar sinnet.

Begrunda då detta:

Att se en stjärna på ljusa dagen

är lika svårt och ovanligt som att finna en dyrbar människokropp.

Lika säkert som att den uppgående solen också går ner är det att den som en gång har fötts också dör.

Begrunda detta!

Lika säkert som att en rättfärdig konung bestraffar brott är orsak och verkan i sanning ofrånkomliga.

Begrunda detta!

Lika säkert som att vi inte står ut med den minsta krämpa är bristerna i tillvarons kretslopp outhärdliga.

Begrunda detta! $!^{135}$ 
När Tsangnyön sjunger till sina närmaste lärjungar, som lever ett helt annat sorts liv än härskarna och ägnar sig åt ihärdig meditation för att förstå sinnets verkliga natur, sjunger han ofta sånger som på ett direkt sätt introducerar lärjungarna till denna natur. Han återkommer ofta till att det är vår tendens att uppfatta tillvaron på ett dualistiskt sätt, samt vår vana att skilja mellan subjekt och objekt, som är själva roten till de problem och lidanden som vi upplever i tillvarons kretslopp. I en sång till sin kvinnliga följeslagare och partner, Kuntu Sangmo, sjunger han till exempel:

\author{
Det inneboende sinnets natur \\ är till sitt ursprung bortom konstlade begränsningar. \\ Subjekt-objekt-uppdelningens allehanda fenomen \\ framträder, men saknar egen natur. \\ När du utövar meditation, \\ måste du vara helt närvarande i enkelhetens tillstånd. ${ }^{136}$
}

Endast i några av sångerna framträder den normöverskridande galna yogin med sitt okonventionella sätt att uttrycka sig och agera. I en av sångerna använder Tsangnyön till exempel fula ord och förklarar det rätta synsättet, meditationen och uppförandet på ett "underhållande sätt". ${ }^{137}$ Denna sång sticker ut från de andra och påminner snarare om någon av den i Tibet och Bhutan så populära galna yogin Drukpa Kunles (1455-1529) sånger. ${ }^{138}$ "Utöva med samma iver som när penisen befinner sig invid slidans öppning", uppmanas Palden Sangpo i sången. Håll de egna inre upplevelserna hemliga såsom "du skyddar en drottning från andras beröring”, fortsätter Tsangnyön. Vidare jämför han de så kallade åtta världsliga angelägenheterna - vinst, förlust, berömmelse, obemärkthet, lovord, förtal, lycka och lidande - med en mage som är fylld av gaser. Gaserna i magen är, precis som de åtta världsliga angelägenheterna, helt onödiga. "Gör dig av med dem!” uppmanar Tsangnyön. ${ }^{139}$

Med undantag av en sång där Tsangnyön kritiserar de som följer de lägre farkosterna, är hans sånger inte lika tydligt kritiska gentemot andra religiösa utövare som Drukpa Kunles sånger ofta är. ${ }^{140}$ Drukpa Kunle kritiserade de flesta religiösa utövare, inklusive sig 
själv, i många av sina sånger. Följande utdrag ur en längre sång av Drukpa Kunle är ett tydligt exempel:

Jag, en ständigt kringvandrande yogi,

besökte ett kagyukloster.

Varje person på kagyuklostret höll en mugg med öl.

Rädd för att bli en fyllerist

höll jag, yogin, mig för mig själv.

Jag, en ständigt kringvandrande yogi,

besökte ett sakyakloster.

Sakyamunkarna ringaktade alla synsätt.

Rädd för att förlora mitt förtroende för dharma

höll jag, yogin, mig för mig själv.

Jag, en ständigt kringvandrande yogi,

besökte ett gelukpakloster. ${ }^{141}$

I gelukpaklostret söktes vänskap och tröst hos unga munkar.

Rädd för att förlora min säd

höll jag, yogin, mig för mig själv.

Jag, en ständigt kringvandrande yogi,

besökte ett meditationscenter.

Där sökte alla meditationsutövare efter en partner.

Rädd för att bli en familjeförsörjande yogi

höll jag, yogin, mig för mig själv.

Jag, en ständigt kringvandrande yogi,

besökte ett nyingmakloster. ${ }^{142}$

I nyingmaklostret ville alla utföra de välsignelsebringande religiösa danserna.

Rädd för att bli en yogi som ägnar sig åt att dansa

höll jag, yogin, mig för mig själv.

$[\ldots]$

Jag, en ständigt kringvandrande yogi,

besökte en avlägsen eremitboning.

Eremiterna satt och slöade i solen.

Rädd för att hamna i en eremitbonings trygghet

höll jag, yogin, mig för mig själv. 
Jag, en ständigt kringvandrande yogi,

besökte en grupp lamor.

De var oupphörligt upptagna med att ta hand om sina tillgångar.

Rädd för att bli en person som samlar rikedom

höll jag, yogin, mig för mig själv.

$[\ldots]$

Jag, en ständigt kringvandrande yogi, vandrade land och rike kring utan något mål.

Vart jag än tittade såg jag självcentrerade människor.

Rädd för att själviska tankar skulle väckas inom mig höll jag, yogin, mig för mig själv. ${ }^{143}$

Det finns uppenbara skillnader mellan Tsangnyöns och Drukpa Kunles sånger. Tsangnyöns sånger har heller inte blivit lika populära och välkända som hans samtida kollegas. Kanske beror detta på att de i första hand riktar sig till hans lärjungar och innehåller direkta råd om hur de ska utöva meditation. En annan orsak kan nog vara att de inte är lika översållade av samhällskritiska, sexuella och humoristiska inslag som Drukpa Kunles sånger.

I en av sina sånger sammanfattar Tsangnyön det huvudsakliga syftet med buddhismen på följande sätt: "Om du verkligen utövar de upphöjdas lära från hjärtat finns inget annat att utöva än att ståndaktigt utplåna jagbundenheten." ${ }^{144}$ På ett mycket drastiskt sätt uppmanar Tsangnyön sina åhörare att grundligt ta död på egoism och själviskhet:

Hugg av jagbundenhetens fötter som går efter sinnesnjutningar!

Skär av dess händer som utför negativa handlingar!

Peta ut dess ögon som ser andras fel!

Skär av dess öron som lyssnar till det orena sinnets röst!

Hugg av dess näsa som nosar efter de osunda tankarnas vind!

Dra ut dess tunga som prisar sig själv och talar illa om andra!

Flå dess kropp som är hyckleri!

Skär av jagbundenhetens stora kroppspulsåder!

Till slut, när du på detta sätt har avrättat den ökände dödsfienden, 
efter ett oändligt antal liv i tillvarons kretslopp,

kasta då också ner jagbundenhetens - fiendens - likrester i den stora gränslöshetens avgrund!

Begrav den i jorden som är den fundamentala likheten av saṃsāra och nirvāna!

Tvätta den i medkänslans vatten som är att hålla andra mer kära än dig själv!

Bränn upp den i kunskapens och visdomens eld!

Låt dess aska blåsa bort i dharmatās vind!

Det är på detta sätt du blir kvitt den hatiska fienden, jagbundenheten! ${ }^{145}$

Ett annat ämne som genomsyrar många av sångerna är vikten av att bry sig om andra. I en sång till hjärtesonen Möndze Togdenpa uttrycker sig Tsangnyön på följande sätt:

Om du saknar medkänsla och förmåga att hålla andra mer kära än dig själv, är även en god förståelse av tomheten, inget annat än det nihilistiska synsättet.

Om medkänslans flod inte strömmar genom ditt sinne och den upphöjda godheten förväxlas med falsk godhet bedrar du dig själv och andra. ${ }^{146}$

Tsangnyön avskydde, i likhet med andra galna yogier, hyckleri och skenhelighet. "En person som inte i sanning tagit avstånd från tillvarons kretslopp i sitt hjärta, utan endast antar den yttre formen av en dharmautövare, och låtsas vara god för att bli känd och respekterad, visar sig vid närmare granskning bedra såväl sig själv som alla andra”, påpekar han i en av sångerna. ${ }^{147}$

I en av sångsamlingens sista sånger undervisar Tsangnyön den mäktiga Dönyö Dorje, den högsta politiska ledaren i Tibet vid denna tidpunkt, om hur han ska styra i samklang med den buddhistiska läran. Han uppmanar bland annat Dönyö Dorje att straffa dem som begår dåliga handlingar, för att på detta sätt direkt demonstrera orsak och verkan. En rättfärdig konung bör, enligt sången, se till att de som handlar orätt får sitt straff redan i detta liv. Tonen i denna sång är annorlunda än i sångerna som är riktade till kungen av Gungtang 
och hans söner. Tsangnyön är påfallande hövlig vilket kanske inte är så konstigt med tanke på att Dönyö Dorje var Tibets mäktigaste man. Han kallar Dönyö Dorje "Kung över de snöhöljda bergens rike" och avslutar sin sång med att önska att Dönyö Dorjes rike, följe, folk, och rikes tillgångar, inte ska avta utan stadigt växa och blomstra. ${ }^{148}$

Sångsamlingen avslutas med de ovan citerade så kallade sista vajrafraserna, de ord som Tsangnyön yttrade innan hans "upplysta sinne smälte samman med rymden" i Rechungpuk. ${ }^{149}$

Tsangnyöns lärjunge Götsangrepa indelar Tsangnyöns sånger i följande kategorier i Det strålande solskenets översikt: $:^{150}$

- sånger med instruktioner (t: gdams pa'i mgur)

- sånger som introducerar sinnets natur (t: ngo sprod kyi mgur)

- sånger med frågor och svar (t: zhus lan gi mgur)

- sånger med instruktioner att bära med sig under en resa (t: 'gro chos kyi mgur).

Denna kategorisering antyder vad sångerna handlar om. Det är dock svårt att särskilja de olika kategorierna från varandra. Alla sånger innehåller till exempel instruktioner.

Det är värt att påpeka att sångerna också hade en praktisk funktion för kringvandrande yogier. Tsangnyön förklarar:

För oss yogier som utövar de två stadierna av meditation och följer medkänslans tradition bidrar sångerna till försörjning ( $\mathrm{t}$ ' 'tsho chas) när vi vandrar på begravningsplatser och mellan heliga platser. De är oumbärliga (t: yo byad) när vi strövar runt i vildmarken och i ensliga bergsområden. Sångerna är offergåvor då vi möter lamor och presenter när vi träffar våra dharmabröder. De är sådant vi kan skänka bort då vi besöker tempel och stūpor. Sångerna är varor som vi kan använda när vi reser runt på landsbygden, de är avgiften för färjan när vi korsar floder, gåvor till kungar, en yxa med vars hjälp vi hugger loss allmosor från de välbärgade, och en fil med vars hjälp vi filar fram allmosor från de fattiga. Till och med när vi stöter på banditer 
svarar vi genom sånger. Sånger som innehåller råd och uppmaningar om att utöva goda handlingar. ${ }^{151}$

\section{Reflektioner kring Tsangnyön Heruka och hans sånger}

Tsangnyöns sångsamling belyser den religiösa och politiska situationen som rådde i Tibet innan Dalai lamorna kom till makten. Genom sångerna framträder en sida av den tibetanska buddhismen som ibland försummats när denna inriktning av buddhism skildrats, men som alltjämt finns kvar som en underström. Dalai lama, munkar och kloster tenderar ibland att överskugga andra sidor av denna mångfasetterade gren av buddhismen. Det är lätt att glömma den viktiga roll som lekfolket (både män och kvinnor), och de kringvandrande yogierna (både män och kvinnor) också har haft. Tsangnyön verkar inte ha tyckt att det spelar någon större roll om man är munk eller lekman, man eller kvinna. Genom hängivenhet och ihärdig utövning finns det en möjlighet för alla att nå framsteg på vägen mot uppvaknande, tycks han ha menat. Tsangnyön förespråkade en återgång till de tidiga, kringvandrande kagyuyogiernas enkla livsstil, fjärran från kloster och städer. Han var inte bara kritisk mot hur vissa lärda geshes inom gelugpaskolan tolkade buddhismen, utan ogillade också den utveckling som hade skett inom hans egen tradition, kagyuskolan. ${ }^{152}$ Det var inte längre särskilt många inom kagyuskolan som levde det enkla asketiska liv som deras förgrundsgestalt Milarepa en gång hade levt. Tsangnyön påminde både sina anhängare och andra om att Milarepas arv måste bevaras och spridas.

Det var framför allt genom att sammanställa och trycka de tidiga kagyumästarnas sångsamlingar och biografier om dem som Tsangnyön fick fram sitt budskap. Milarepa och Marpa fick exemplifiera de ideal som Tsangnyön ansåg var på väg att gå förlorade. Han nöjde sig dock inte med att endast via böcker presentera det ideal han ville återuppliva - han och hans lärjungar visade också att det fortfarande gick att leva såsom Milarepa och de indiska siddhorna en gång hade levt. Tsangnyön sjöng själv sånger, mediterade i samma grottor som Milarepa hade mediterat i, vandrade samma vägar som den bomullsklädda yogin hade gått på och praktiserade samma meditationsmetoder. Gränsen mellan Tsangnyön och Milarepa var 


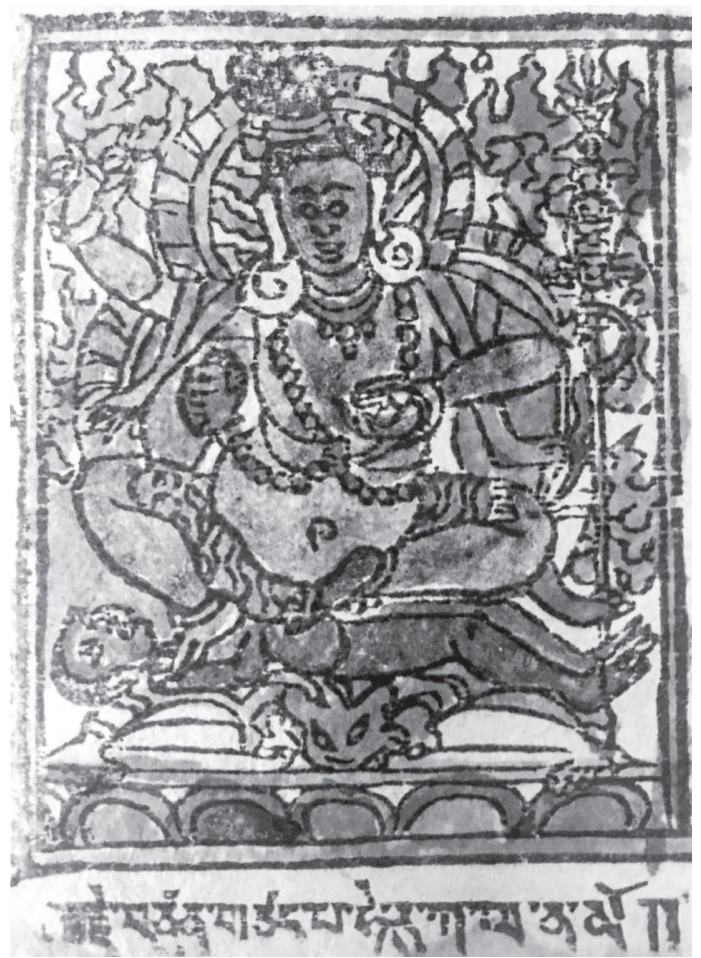

Bild 10. Tsangnyön (gTsang smyon he ru ka, gTsang pa he ru ka'i mgur 'bum: 1b).

på så vis inte bara flytande, utan upplöstes helt. Tsangnyön framstod som Milarepa inkarnerad, och liksom Milarepa ansågs han vara en fullkomnad, en siddha.

Detta är ju också själva syftet med de utövningar som Tsangnyön ägnade sig åt. Genom att utveckla hängivenhet och identifiera sig med sin lärare och med tidigare mästare i traditionen, så kallad guruyoga, försvinner skillnaderna mellan lärjunge och mästare. Och genom att identifiera sig med sin utvalda meditationsgudomlighet, sin yidam, upplöses gränsen mellan den som mediterar och meditationsobjektet. Med hjälp av dessa metoder finns det enligt den tantriska buddhismen möjlighet att nå uppvaknandet under ett enda liv. På grund av att Tsangnyön uppfattades vara en förverkligad mästare, en reinkarna- 
tion av Milarepa, fick hans sånger och övriga aktiviteter sannolikt en tyngd och en tillförlitlighet som många andra samtida mästares förkunnelser och handlingar saknade.

Trots att Tsangnyön identifierade sig starkt med Milarepa och till och med uppfattades vara dennes inkarnation, verkade han ha varit kritisk till reinkarnationssystemet, som blev alltmer allmänt förekommande under hans livstid. Det var viktigare att leva såsom de tidigare mästarna hade gjort än att tillhöra någon speciell reinkarnationslinje, hävdade han. När han fick frågan om han själv var en reinkarnation av Tilopa eller någon annan kagyumästare, svarade han vid ett tillfälle: "Jag upprätthåller visserligen Tilopas tradition, men jag har ingen aning om jag är hans reinkarnation eller inte." ${ }^{153} \mathrm{I}$ sin biografi om Milarepa framhöll Tsangnyön att Milarepa varit en vanlig människa som, med hjälp av sin exceptionella ihärdighet och sitt djupa förtroende för sin lärare och dennes instruktioner, lyckats nå uppvaknandet $\mathrm{i}$ ett enda liv. Därmed valde Tsangnyön att gå emot samtliga tidigare Milarepabiografer som framställt den bomullsklädda yogin som en emanation av en buddha. ${ }^{154}$ När han framhävde att Milarepa varit en vanlig ofullkomlig människa innan han blev en förverkligad mästare, gjorde han det möjligt för läsaren av livsberättelsen att identifiera sig med Milarepa. Detta var förmodligen en av orsakerna till att Tsangnyöns biografi om Milarepa blev populär och inspirerande för läsaren.

Precis som Milarepa föredrog Tsangnyön och hans lärjungar i allmänhet att vistas på avlägset belägna platser som låg långt från maktcentra och färdvägar. Trots detta, eller kanske snarare på grund av detta, lyckades Tsangnyön vinna världsliga härskares förtroende och stöd. Det var tack vare sina relationer till härskare, alltså välgörare-lärare-relationer, som Tsangnyön kunde få de resurser som krävdes för att genomföra de kostsamma projekt som gjorde honom berömd, såsom boktryckning och renovering av Svayambhūstūpan i Nepal. Enligt biografierna hade Tsangnyön välgörare-lärare-relationer med bland annat följande härskare: Dönyö Dorje, Tibets mäktigaste man som styrde över stora delar av Tibet under slutet av 1400-talet och början av 1500-talet; kungen av Katmandu, Ratnamalla, som styrde 1484-1520; Tashi Targye (d. 1499) som styrde över provinsen Ja; Tashi Gön (d. 1489), härskare i Mustang; Namgyel De (1422-1502) 
samt dennes bägge söner Norbu De (1450-1485) och Samdrub De (1459-1505) som styrde i Mangyul Gungtang. ${ }^{155}$ Även härskarna av norra och södra Latö var hängivna lärjungar och välgörare som stödde Tsangnyön och hans lärjungar. ${ }^{156}$ I sångsamlingen ingår sånger riktade till några av ovan nämnda härskare och dessutom till kung Sherab Palsang som var halvbror till Samdrub De och Norbu De, samt sånger till Dzamling Gyalmo som var halvsyster till kung Tri Namgyel De. Där återfinns också sånger riktade till härskarinnan av Tenkheb, Sönam Sangmo.

Tsangnyön levde under en kaotisk och konfliktfylld men samtidigt dynamisk och kreativ period av Tibets historia. Det verkar ha funnits vissa fördelar med att vara en kringvandrande yogi under de stundtals svåra omständigheter som rådde i landet under 1400- och 1500-talet. Tsangnyön och hans lärjungar var inte bundna till något specifikt kloster eller någon specifik region. Om konflikter och krig bröt ut i ett område vandrade de helt sonika vidare till en annan plats. Genom att förorda ett avståndstagande från världsliga strävanden tycks den kringvandrande yogin ha uppfattats som oberoende och neutral, vilket gjorde det möjligt för honom eller henne att etablera välgörare-lärare-relationer med flera olika ledare och agera medlare i konflikter.

Det var av allt att döma inte någon slump att det var just under 1400- och 1500-talet som de mest välkända heliga dårarna vandrade runt i Tibet. Förutom Tsangnyön bör Drukpa Kunle (1455-1529), ${ }^{157}$ Unyön Kunga Sangpo (1458-1532) ${ }^{158}$ och Tangtong Gyalpo (1361$1485)^{159}$ omnämnas. Dessa färgstarka individer var kringvandrande yogier och tillhörde i allmänhet kagyuskolan. Kagyuskolan var den mest inflytelserika traditionen under denna tid och gelugpaskolan hade ännu inte fått det stora inflytande som den så småningom skulle få. De heliga dårarna verkade dra nytta av den rådande situationen. Utan någon självklar centralmakt som kunde skapa enhetlighet fanns det utrymme för ovanliga och excentriska utövare. Det fanns dessutom gott om lokala härskare som var beredda att ge stöd åt färgstarka kagyuyogier som valde att leva utanför klostrens murar. Det verkade ingå i den heliga dårens roll att uttrycka sig ärligt, drastiskt och humoristiskt. Därmed kunde Tsangnyön kritisera härskare och allteftersom hans anseende växte även påverka politiska skeenden. 
Det finns några olika tekniska termer som används för det normöverskridande och ibland till synes galna uppförande som ledde till att Tsangnyön fick sitt namn, ”Dåren från Tsang”. Den mest vanligt förekommande termen i biografierna är "disciplinerat uppförande" (t: brtul zhugs spyod pa; s: vratacaryā) eller kort och gott "uppförande" (t: spyod pa; s: caryā). ${ }^{160}$ Detta uppförande omnämns i de tantriska texter som Tsangnyön hade studerat, praktiserat och fulländat i Palkor Chöde. Där nämns det när, var, hur, av vem och varför "uppförandet" ska tillämpas. Syftet med denna säregna utövning var bland annat att undanröja de sista subtila hindren som skymmer sinnets sanna natur, för att därigenom snabbare uppnå uppvaknandet. Bland flera olika typer av uppföranden som den yogi som utövar enligt denna disciplin kan ägna sig åt återfinns det galna uppförandet. Genom att utövaren avsiktligt uppför sig på ett till synes galet sätt och utsätter sig för situationer som frammanar rädsla, begär, aggression eller andra orenheter i sinnet, tvingas han eller hon att konfronteras med sidor av sig själv som annars skulle ha förblivit dolda. Det rör sig om en svår och farlig praktik som kan få katastrofala följder om utövaren inte kan hantera de känslor och situationer som han eller hon avsiktligt frammanat. Det varnas för att dessa övningar leder till en lägre återfödelse i tillvarons kretslopp om de utförs av någon som inte har de nödvändiga insikterna och förkunskaperna som disciplinerat uppförande kräver. Eftersom allehanda normöverskridande uppföranden, inklusive sexuell aktivitet, ingår i denna praktik så är den oförenlig med munklöftena. Tsangnyön valde också att sluta vara munk innan han påbörjade denna avancerade tantriska utövning.

Till synes galet uppförande kan också ses som ett resultat av utövningen. När målet med utövningen är uppnått förändras den självcentrerade världsbild som tidigare varit utgångspunkten för utövarens sätt att tänka, känna och agera. Han eller hon är inte längre intresserad av de åtta så kallade världsliga angelägenheterna som människor i allmänhet bygger sin tillvaro kring. Det är helt oväsentligt om han eller hon vinner eller förlorar, blir berömd eller inte blir berömd, får lovord eller blir förtalad, upplever lycka eller lidande. En sådan utövare har således helt andra utgångspunkter för sitt sätt att tänka, känna och handla än en människa som motiveras av att vinna, bli berömd, få lovord och uppleva lycka och som gör allt som står i hennes 
makt för att undvika förlust, obemärkthet, förtal och lidande. När världsliga angelägenheter inte längre intresserar utövaren uppfylls han eller hon i stället av osjälviskhet, visdom och medkänsla. En sådan person kan, eftersom han eller hon uppför sig och tänker så diametralt annorlunda än andra, förefalla galen utifrån en egoistisk och självcentrerad människas oupplysta perspektiv. Enligt det buddhistiska synsättet har dock han eller hon i själva verket insett sin egen och tillvarons verkliga natur och det är snarare de som inte gjort detta som är galna.

\section{Några kommentarer till översättningen}

Tsangnyön Herukas sånger är organiserade i kronologisk ordning och fungerar därför, tillsammans med de omgivande ramberättelserna, som en sorts biografi över Tsangnyöns vuxna liv. Vi får följa honom från det att han sjunger sin första sång i tjugoåttaårsåldern, till dess att han sjunger sin sista, strax före sin bortgång. Sångsamlingen består enligt kolofonen av tjugosju sånger. Sex av dessa bär benämningen "storslagna sånger" (t: mgur chen) och var välkända i Tsangnyöns samtid enligt sångsamlingens kolofon. Det är något oklart varför dessa sånger kallas för storslagna. Det har inte med sångernas längd att göra, men kanske var de särskilt betydelsefulla och omtyckta. Det är värt att notera att det faktiska antalet sånger är fler än tjugosju. Sångsamlingen innehåller i själva verket mer än trettio sånger, men eftersom några av sångerna består av flera sånger som hör ihop med varandra har de räknats samman av den som sammanställt samlingen. Dessutom ingår ett par sånger som inte tillskrivs Tsangnyön utan en lärjunge respektive en kung som han träffade på. Deras sånger räknas inte heller in i det totala antalet.

Troligtvis finns inte de träblock bevarade som tillverkades 1508 och användes när sångsamlingen ursprungligen trycktes upp. Däremot finns ett fåtal blocktryck av de texter som framställdes med hjälp av dessa träblock kvar. Dessa ytterst sällsynta texter har mig veterligen inte gjorts tillgängliga i bokform, men de finns avfotograferade, dels i BDRC:s digitala arkiv över tibetanska texter (www.tbrc.org), dels i The Nepal-German Manuscript Preservation Projects (NGMPP) arkiv över mikrofilmer i Nepal. 
Till min hjälp när jag studerat sångerna har jag haft två biografier om Tsangnyön, där de flesta av sångerna ingår: Götsangrepas (rGod tshang ras pa) Tsangnyönbiografi från 1512 och Lhatsun Rinchen Namgyels (lHa btsun rin chen rnam rgyal) Tsangnyönbiografi från 1543. Dessa bägge biografier är sällsynta, men finns tillgängliga i tryckt format på ett fåtal bibliotek (dock inget i Sverige) ${ }^{161}$ Biografiernas titlar och övriga bibliografiska uppgifter finns angivna i litteraturlistan för dem som önskar få tag även på dessa texter.

Utöver själva sångsamlingen har jag också översatt en kort översikt över Tsangnyöns sånger av Tsangnyöns lärjunge Götsangrepa, som för övrigt också var med och sammanställde sångsamlingen. Denna översikt bär namnet Det strålande solskenets översikt och finns endast i ett känt exemplar. ${ }^{162}$ Mycket tyder på att denna raritet sammanställdes och trycktes samtidigt som själva sångsamlingen. ${ }^{163}$ Där anges inte bara vilka sånger som ingår i sångsamligen, utan där finns i allmänhet också uppgifter om var sångerna sjöngs och till vem de riktades. Dessutom anges i korthet vad de olika sångerna handlar om, och ibland också deras titel. Vidare påpekas det om sången var en så kallad storslagen sång eller inte. Ibland inkluderar Götsangrepa information som saknas i själva sångsamlingen, vilket gör hans översikt till ett viktigt komplement. Götsangrepas översikt är särskilt användbar om man vill förstå hur sångsamlingen är uppdelad. Jag hade stor nytta av den när jag delade upp sångsamlingen i avsnitt och valde rubriker för dessa avsnitt.

Sångerna är skrivna i metriskt bunden form, med olika versmått, men ramberättelserna är inte skrivna på vers. Det vanligaste antalet stavelser per versrad i sångerna är sju eller nio. Ibland förekommer åtta eller sex stavelser per versrad. ${ }^{164}$ Stundom växlar stavelseantalet i en och samma sång, men vanligtvis bevaras samma antal stavelser per rad sången igenom. Det fixerade antalet stavelser per versrad gör att sångerna kan reciteras eller sjungas. Metriskt bunden text är också enklare att memorera, vilket var viktigt med tanke på att de flesta av sångerna sannolikt traderades muntligt innan de skrevs ner och trycktes.

Att översätta metriskt bunden text kan vara vanskligt. Eftersom det är stor skillnad mellan svenska och tibetanska är det oerhört svårt att bibehålla det bundna formatet i en översättning. Ett ord som på 
tibetanska är två stavelser långt är ofta mer än dubbelt så långt på svenska. Ibland tvingas man som översättare dessutom konstruera relativt långa och komplicerade fraser som består av flera ord när man översätter korta och enkla tibetanska ord som saknar motsvarighet på svenska. Detta gör att det är i det närmaste omöjligt att bevara sångernas metriska struktur, utan att innebörden förändras. I stället tvingas översättaren skriva sångerna i obunden form. Detta medför dessvärre att det blir svårt att recitera eller sjunga sångerna i översättning, och därmed försvinner en viktig dimension av dem - sångerna är ju trots allt tänkta att sjungas eller reciteras. ${ }^{165}$

Det är också svårt att i översättning fånga in ordlekar och rent ljudmässiga aspekter av sångerna. Det är även vanskligt att bevara den stilistiska skönhet som återfinns i den tibetanska texten. Översättaren tvingas ofta att välja mellan att hålla fast vid antingen form eller innehåll. I denna översättning har innehållet prioriterats på formens bekostnad.

Eftersom grammatiska partiklar ibland fattas och ord och namn stundom förkortas för att upprätthålla det givna antalet stavelser i versen, kan det vara besvärligt att förstå vissa enskilda strofer i en sång. Ibland har också partiklar och utfyllnadsord som inte betyder något lagts till för att behålla versmåttet. Sångernas innehåll är dessutom ofta esoteriskt och djupsinnigt vilket inte sällan gör dem svårtolkade. Lägg därtill att många av sångerna innehåller exempel, liknelser, idiomatiska uttryck och talesätt som kanske tedde sig enkla och solklara för en tibetan på 1500-talet, men som kan vara svåra att förstå och relatera till för en västerlänning som lever i en helt annan kultur och tid. Med tanke på dessa olika faktorer är det häpnadsväckande att sångerna är så pass begripliga och talande för en svensk läsare som jag uppfattar att de är.

Det tibetanska språket är konstruerat på ett sådant sätt att pronomen och annat som inte är helt nödvändigt för att läsaren ska förstå meningen ofta utelämnas. Om det till exempel framgår av sammanhanget vem som utför en handling finner tibetanerna det onödigt att benämna honom eller henne. En vanlig tibetansk mening kan således vara "Sen gick till Tsari". Denna mening är ofullständig på svenska, och för att göra den fullständig behöver vi lägga till vem det var som gick till Tsari, det vill säga: "Sen gick [Tsangnyön] till Tsari." Den 
här typen av meningar är mycket vanliga i ramberättelserna. För att visa att det var just Tsangnyön som gick till Tsari, och inte någon av hans lärjungar, används i allmänhet en speciell verbform som endast används om den som utför handlingen har en upphöjd status. Tibetanerna visar således med verbet vem som är subjekt.

Tsangnyön kallar sig själv för "jag, yogin" (rnal 'byor nga) eller "jag, den galna yogin" (rnal 'byor smyon pa nga) i några av sångerna. Lärjungarna kallar honom för "mästaren" (rje), "den dyrbare mästaren" (rje rin po che), "fader siddhan" (pha grub thob) eller andra respektfulla benämningar i sångernas ramberättelser. Namnet Tsangnyön används i princip inte alls. Det är dock under detta epitet som han kom att bli känd och jag har därför valt att kalla honom just Tsangnyön, "dåren från Tsang", när jag infogat hans namn i texten.

Sångerna riktar sig i allmänhet till en eller flera personer och vem eller vilka som Tsangnyön sjunger till klargörs genom ramberättelsen och ofta också i början av sången. För att tydliggöra vem sången riktar sig till och göra de enskilda stroferna i sången fullständiga behöver man ofta lägga till denna information i själva sången. Ord som "du", "ni" eller namnet på den som sången riktar sig till behöver infogas så att meningarna blir fullständiga och sången begriplig. Jag har valt att lägga till sådana utelämnade pronomen och namn i både sångerna och i ramberättelserna, och ibland även annat, för att göra meningarna fullständiga och grammatiskt korrekta. Det finns en praxis i akademiska kretsar att markera sådant som lagts till i en översättning med hakparenteser (som jag gjorde i exemplet ovan), men om jag genomgående skulle göra det skulle översättningen vara fullständigt översållad av hakparenteser. Det skulle störa läsningen. Dessutom anser jag att det inte är nödvändigt, eftersom tilläggen egentligen bara innebär att jag skrivit ut sådant som sången faktiskt redan uttrycker men på ett annat sätt än vad vi är vana vid.

En annan egenhet hos dessa sånger är att de innehåller en mängd olika tekniska ord och uttryck som har med buddhismen att göra, till exempel "de två samlingarna", "de tre tiderna", "subjekt-objektuppdelningen", "en smak" och "ren syn". Dessa buddhistiska ord och uttryck förklaras i ordlistan som finns i slutet av boken. Där anges i vissa fall ordens och uttryckens ekvivalenter på tibetanska och ibland även på sanskrit. Jag har endast undantagsvis använt noter när den 
här typen av tekniska ord och uttryck dyker upp i sångerna, och jag har inte heller använt mig av citationstecken för att markera dem. Om jag hade markerat alla sådana ord och satt noter vid dem skulle översättningen vara full av citationstecken och noter. Detta tror jag skulle störa läsningen av sångerna. Min förhoppning är att läsaren efter hand ska bekanta sig med dessa buddhistiska termer och uttryck. Om läsaren glömt vad till exempel "de tre tiderna" syftar på kan han eller hon titta i ordlistan.

Det är viktigt att vara medveten om att sångerna är dikter som kan tolkas på olika sätt. Det finns olika praxis kring hur man bör göra vad gäller kommentarer till dikter. Somliga väljer att helt undvika såväl kommentarer som noter så att läsaren ska kunna tolka dikten självständigt. Detta förutsätter dock att läsaren är insatt i poetens språkbruk och förstår de liknelser och termer som används i dikterna. Eftersom dessa dikter kommer från en fjärran tid och en för många läsare främmande kultur känns det nödvändigt att bistå läsaren med viss information för att på så sätt underlätta förståelsen av sångerna. Det är också praxis att använda kommentarer efter varje enskild dikt i stället för noter. Jag har valt att använda ett fåtal noter i sångerna, men har en relativt utförlig ordlista i slutet av boken. Denna lösning gör att sångsamlingen inte blir upphackad av kommentarer och gör det möjligt att läsa sångerna på olika sätt. De som så önskar kan läsa slutnoter och slå upp ord i ordlistan, medan de som föredrar att läsa sångerna som de är och själva tolka dem kan göra det.

För att även läsare utan förkunskaper ska kunna förstå och uppskatta boken har främmande ord i största möjliga mån undvikits i den löpande texten. Min ambition har varit att undvika ord på tibetanska och sanskrit, men det är i vissa fall svårt att hitta lämpliga ord på svenska. När jag inte lyckats hitta ett motsvarande svenskt ord (till exempelvis sanskrittermerna dharmatā och dharmakāya) eller när sanskritordet eller det tibetanska ordet är allmänt känt (som till exempel sanskritordet buddha eller det tibetanska ordet lama) har jag ibland valt att frångå min strävan att använda svenska ord. Boken innehåller också många tibetanska namn på personer och platser. Dessa namn har inte översatts till svenska, och de har återgivits enligt uttal, inte enligt stavning. Orsaken till detta är att uttalet och stavningen skiljer sig mycket åt i tibetanska: Milarepa stavas till exempel Mi la ras pa 
och lama stavas bla ma. I noterna, ordlistan och i parenteserna har jag dock ofta angett den tibetanska stavningen.

Översättningen innehåller endast ett fåtal sanskritord, och när dessa återges har diakritiska tecken använts, det vill säga att jag anger samsāra i stället för samsara. Detta är mer exakt och korrekt och borde inte vålla något problem för läsare utan sanskritkunskaper, eftersom orden är lätta att läsa även när diakritiska tecken används.

Vid några få tillfällen förekommer också sanskritord i den tibetanska originaltexten. Eftersom sångsamlingens författare valt att återge dessa ord på sanskrit har jag valt att inte översätta dem. Många av sångerna inleds till exempel med sanskritorden namo guru, en hyllningsfras till läraren som på svenska skulle kunna motsvaras av "jag bugar mig inför läraren". Nästan alla sånger avslutas med det tibetaniserade sanskritordet evaṃ. Denna term används för att på ett högtidligt sätt markera att en sång är slut och påminner på vissa sätt om den kristna termen "amen". Evam betyder ungefär "så är det", och lärda tibetaner förklarar att de två stavelserna som ordet består av, $e$ och vaṃ, uttrycker buddhismens slutgiltiga mål: den fullständiga föreningen av insikten av tomheten (e) och de skickliga metodernas sällhet (vam).

Slutligen är det viktigt att påpeka att sångerna innehåller direkta, muntliga instruktioner riktade till meditationsutövare som önskar förstå sinnets natur och som förväntas ha erfarenhet och kunskap om den buddhistiska utövningsvägen. För att till fullo förstå sångerna och för att kunna utöva i enlighet med sångernas anvisningar är det nödvändigt att få vägledning av en kunnig och erfaren lärare som tillhör den utövande traditionen. 